\title{
A Rare Pattern of Angiogenesis in Meningiomas: Glomeruloid Microvascular Proliferation
}

\author{
Menenjiyomlarda Nadir Görülen Bir Anjiyogenez Paterni: \\ Glomerüloid Mikrovasküler Proliferasyon
}

\author{
Nilufer ONAK KANDEMIR ${ }^{1}$, Zubeyde ILKE NARLI ${ }^{1}$, Murat KALAYCI $^{2}$, Sukru Oguz OZDAMAR ${ }^{1}$ \\ ${ }^{1}$ Bulent Ecevit University, School of Medicine, Department of Pathology, Zonguldak, Turkey \\ ${ }^{2}$ Bulent Ecevit University, School of Medicine, Department of Neurosurgery, Zonguldak, Turkey
}

Corresponding Author: Nilüfer ONAK KANDEMIR / E-mail: niluferkandemir@yahoo.com

\begin{abstract}
Glomeruloid microvascular proliferation (GMP) is a localized proliferation of vascular endothelial cells resembling a renal glomerule. The nature of cells participating in the formation of these structures remains unclear. While it is a characteristic feature of glioblastoma, it is rarely seen in other solid tumors. Presence of diffuse GMP in meningiomas is characterized by peritumoral edema and an atypical contrast uptake in radiological imaging. Due to its rare nature, a case of spinal meningioma comprising distinct GMP was presented in this study in company with literature data. Also provided a discussion on the pathogenesis of this unusual pattern of angiogenesis and its relationship with tumors biological behavior.
\end{abstract}

KEYWORDS: Meningioma, Glomeruloid microvascular proliferation, Angiogenesis, VEGF

öz

Glomerüloid mikrovasküler proliferasyon (GMP); vasküler endotelyal hücrelerin renal glomerüllere benzer yapılar oluşturan lokalize proliferasyonlarıdır. Bu yapıları oluşturan hücrelerin özellikleri henüz tam olarak aydınlatılamamıştır. Glioblastom' un karakteristik özelliği olan GMP, diğer solid tümörlerde nadir görülmektedir. Menenjiyomlarda yoğun GMP varlığı, peritümöral ödem ve radyolojik görüntülemede atipik kontrast madde tutulumu ile karakterizedir. Bu çalışmada, belirgin GMP içeren spinal menenjiyom olgusu, nadir görülmesi nedeniyle literatür bilgileri eşliğinde sunulmuştur. Bu farklı anjiogenez paterninin patogenezi ve tümörün biyolojik davranışı ile ilişkisi tartışımıştır.

ANAHTAR SÖZCÜKLER: Menenjiyom, Glomerüloid mikrovasküler proliferasyon, Anjiyogenez, VEGF

\section{INTRODUCTION}

Meningiomas are neoplasms originating from arachnoid cells, which are related with the inner layer of dura mater. They form $25-30 \%$ of the primary intracranial neoplasms and are usually seen in middle or advanced ages. The vast majority of meningiomas arise in intracranial, intraspinal or orbital locations. Most spinal meningiomas occur in the thoracic region (3). Meningiomas are highly vascularized tumors; in the majority of cases, the tumor's rich vascular network is originated from a pial vascular supply (6). Microvascular density (MVD) of meningiomas is believed to be a parameter related with tumor progression, histological grade, and prognosis (5).

In recent years tumor angiogenesis is a hot topic of research due to its prognostic value and potential importance in offering novel treatment options. Traditionally, the angiogenic potential of a tumor is measured by MVD (14). Some researchers have argued that the pattern of angiogenesis described as glomeruloid microvascular proliferation (GMP) reflects the angiogenic potential of the tumor better than MVD (13). GMP is a vascular proliferation forming structures that resemble renal glomerules. These vascular structures are composed of mitotic active endothelial cells forming layers, and pericytes. GMP, the characteristic histological feature of the glioblastoma, is rare in other solid organ tumors (8).

As it is a rare pattern of angiogenesis, a case of spinal meningioma containing a marked GMP in tumor-related stroma was presented in company with literature data on etiopathogenesis in the present study

\section{CASE REPORT}

\section{Clinical History}

A 33-year-old female patient presented with neck pain, and drowsiness in right arm and hand for 3 months. Neurologic examination revealed right hemiparesis, hypoesthesia, and hyperreactive deep tendon reflexes. Magnetic resonance (MR) imaging showed an intradural, extramedullary mass with dural connection that was located in 2-4th cervical vertebrae and was hypointense in T2 and isointense in T1 (Figure $1 \mathrm{~A}-\mathrm{C}$ ). On radiological examination, the lesion had a homogenous contrast uptake while no marked peritumoral edema was observed. Laboratory investigations revealed normal hematological and biochemical parameters. Serum 
tumor markers were normal. Under the light of clinical and radiologic findings the mass was totally excised with an initial diagnosis of meningioma. It was noticed during the operation that the mass did not invade the spinal cord, but adhered to adjacent dura. Main vascular supply of the mass was of dural origin. Postoperative MRI showed no residual disease.
After two months of surgery, the patient's symptoms resolved immediately and her neurological examination was normal.

\section{Pathological Findings}

A cream coloured lesion of $3 \times 1,5 \times 1 \mathrm{~cm}$ having a smooth external surface, and a solid and nodular cross-section was

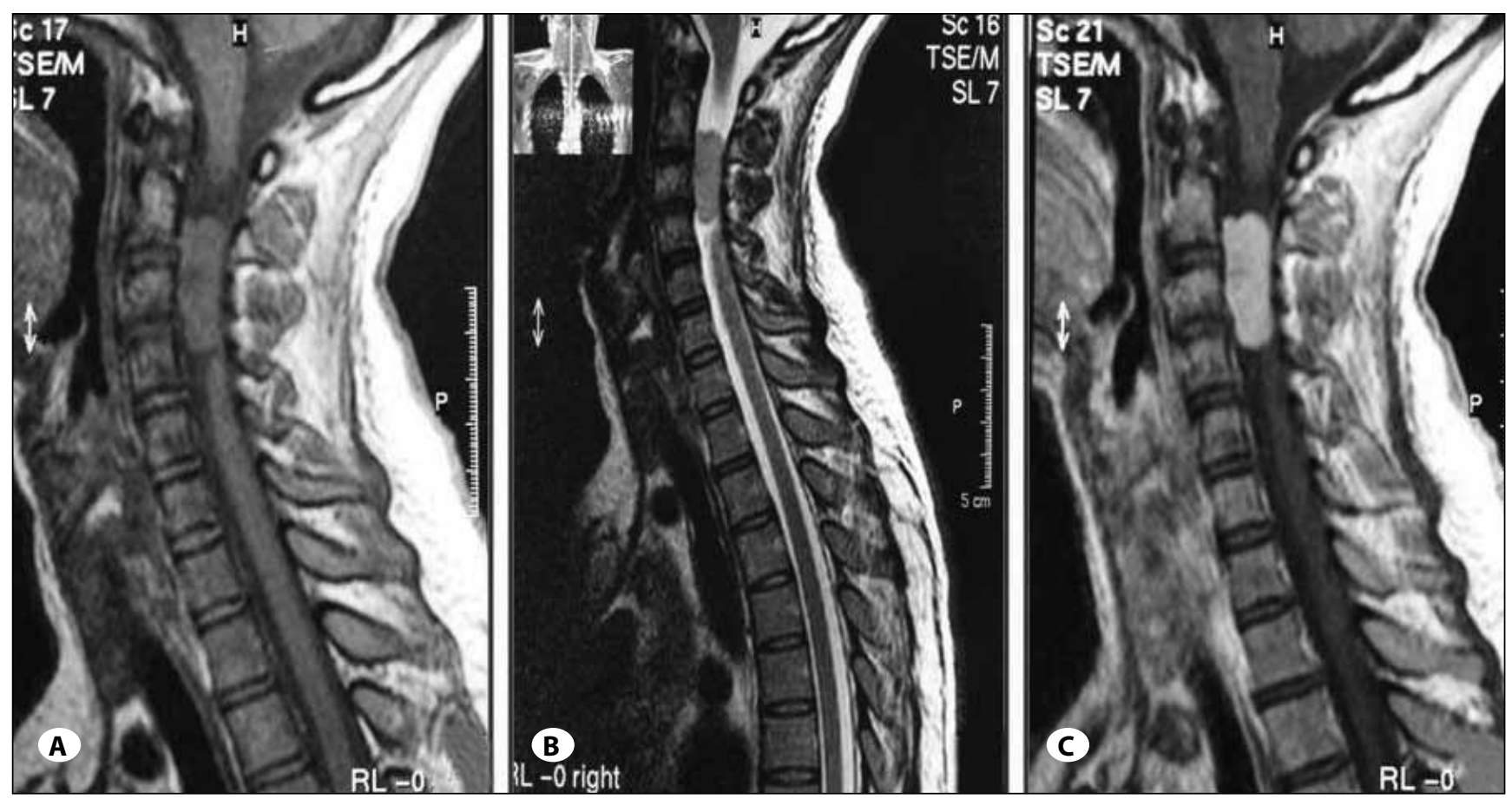

Figure 1: A) T1-weighted sagittal MRI section shows an extra-axial isointense lesion that begins at C2 and extends to upper border of (4. B) The lesion appears hyperintense in the T2-weighted image of the same section. C) The lesion takes up contrast material homogenously while a small "dural tail" is observed antero-superior to the lesion in the T1 image with contrast of the same section.
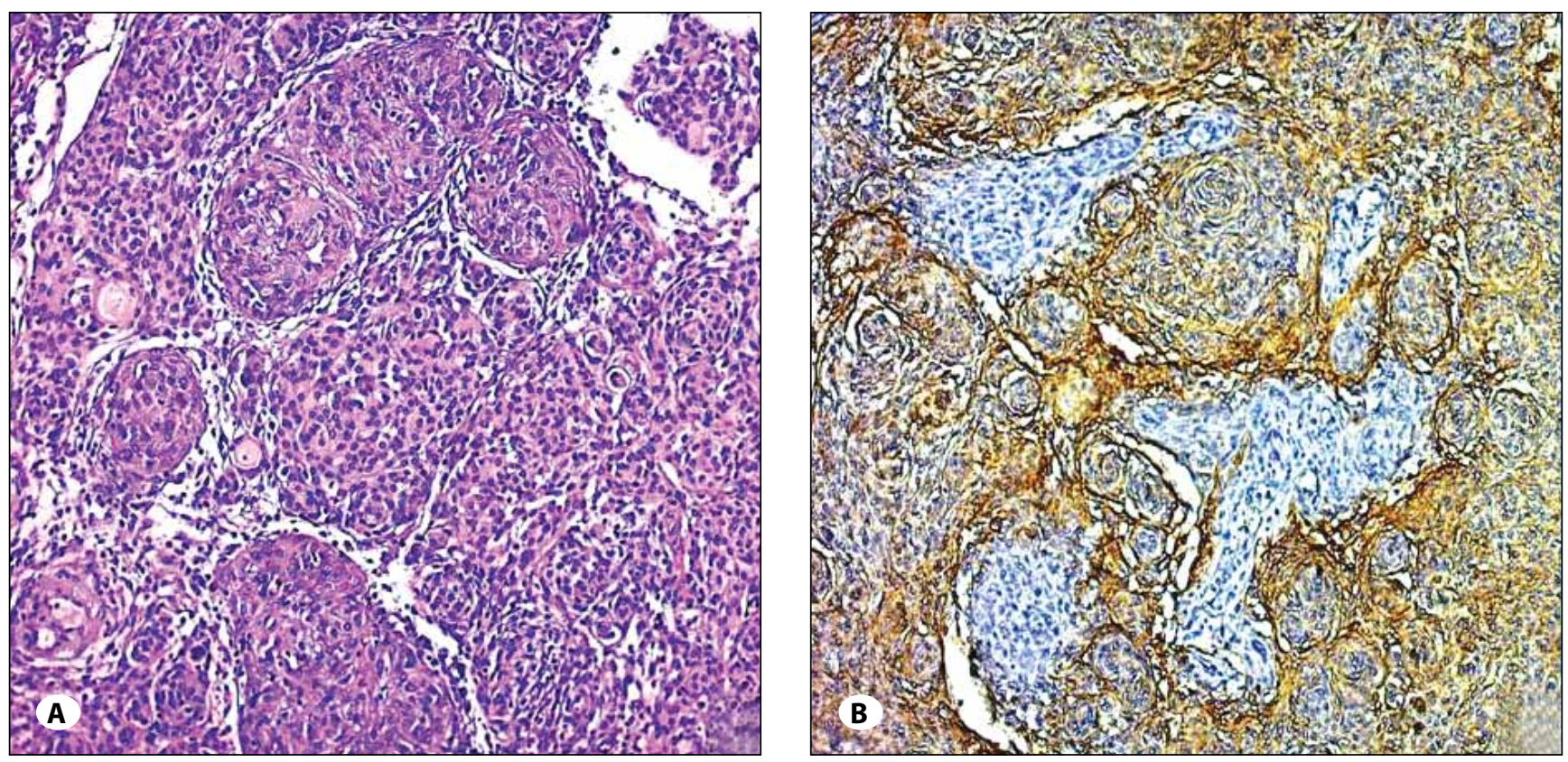

Figure 2: A) In the sections areas of microvascular proliferation forming glomeruloid structures are observed between solid tumor islets $(H-E, x 50)$. B) A positive reaction with EMA is evident in tumor cells surrounding areas of GMP (BSA-DAB, x50). 
observed in macroscopic examination of the operation material.

Pathological examination revealed that the biopsy material was formed fully by the tumor and there was no sign of spinal cord invasion. The surgical specimens were fixed in $10 \%$ neutral buffered formalin, and processed routinely in paraffin blocks and stained with hematoxylin and eosin $(\mathrm{H}$ \& E). Immunohistochemical stains were performed with the aviditin-biotin peroxidase complex $(A B C)$ method and visualized with diaminobenzidine (DAB). The following primary antibodies were used: mouse monoclonal antihuman Vimentin [1:100 dilution, clone V9, DAKO, Carpinteria, CA, USA], polyclonal S-100 (1:100 dilution, DAKO, Carpinteria, CA, USA), smooth muscle actin (SMA [1:100 dilution, clone 1A4, DAKO, Carpinteria, CA, USA]), epithelial membrane antigen (EMA [1:100 dilution, clone E29, DAKO, Carpinteria, CA, USA]), glial fibrillary acidic protein (GFAP [1:100 dilution, clone 6F2, DAKO, Carpinteria, CA, USA]), vascular endothelial growth factor-A (VEGF-A [1:100 dilution, clone VG1, DAKO, Carpinteria, CA, USA]), estrogen receptor (ER [clone 6F11; dilution 1:150; Novocastra, Newcastle, UK]), progesterone receptor (PR [Clone 1294; dilution 1:150; Dako, Carpinteria, CA, US]), as previously described (15).

Examination of the $H \& E$ sections revealed whirl-like solid aggregates formed by monomorphic tumor cells with oval nuclei having a fine chromatin pattern and an indistinct cytoplasmic border. Some tumor islets had psammoma bodies at their center. Foci of microvascular proliferation that formed glomeruloid patterns were observed in tumor stroma. These structures were composed of capillary structure with a narrow lumen that anastomozed with each other and accompanied by endothelial proliferation. Diffuse pericytic proliferation was present at vessel walls. Foci of GMP were forming $20 \%$ of tumor tissue (Figure $2 A, B$ ).

In immunohistochemical examination the tumor cells were strong positive for vimentin, EMA, PR, and VEGF, whereas they were negative for GFAP. Tumor's proliferative index with Ki67 was below 5\%. No increase of mitotic activity, necrosis, cellular atypia, or pattern loss was observed in tumoral tissue. Endothelial cells in the areas of GMP had a positive immunoreaction with CD31 and CD34, and pericytic cells had a positive immunoreaction with SMA. With Ki67, a marked increase of proliferative activity was evident in cells that formed GMP (10\%). In areas of GMP a, focal, weak VEGF immunopositivity was observed in endothelial cells and pericytes (Figure 3A,B; 4A-D).

Underthelight ofhistopathologicalandimmunohistochemical findings the lesion was diagnosed as a GMP-containing meningothelial type meningioma (WHO grade I).

\section{DISCUSSION}

GMP (previously called vascular endothelial proliferation [VEP] or florid microvascular proliferation), is a characteristic histopathological feature of glioblastomas. In glioblastomas GMP is located close to areas of necrosis and thrombosis is common in lumen of vascular structures. Histologically, GMP is characterized by glomeruloid structures consisting of multilayered, mitotically active endothelial cells and pericytes. The ki-67 proliferation index is over $10 \%$ in proliferated vascular structures. Although rare, GMP has been also reported to exist in gliotic tissue surrounding metastatic carcinomas, intracranial granulation tissues, and some glioneuronal
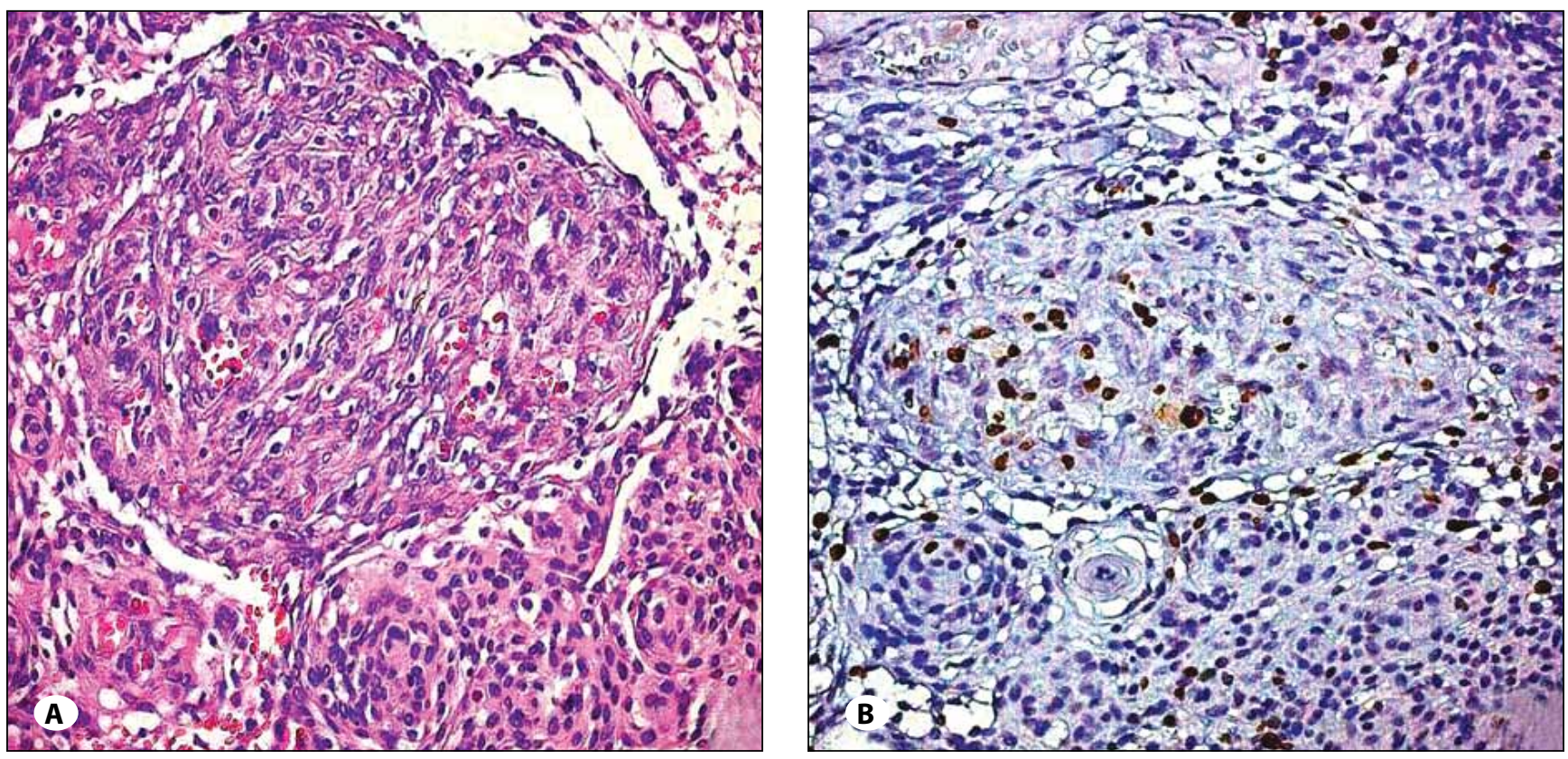

Figure 3: A) Glomeruloid structures formed by proliferated endothelial cells are observed $(H-E, x 100)$. B) An increase in the proliferative activity of the endothelial cells is noted with Ki67 monoclonal antibody (BSA-DAB, x100). 

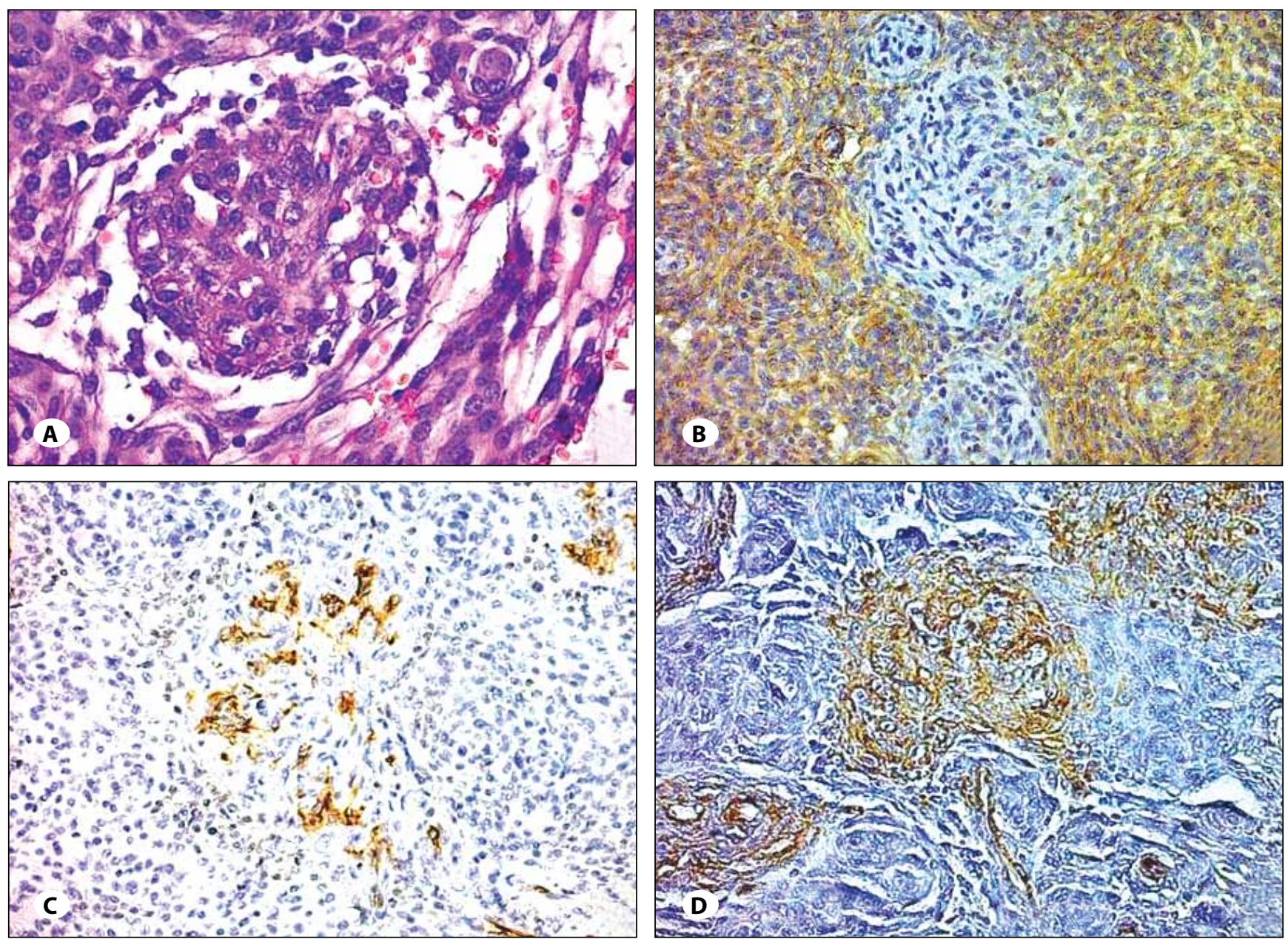

Figure 4: A) Glomeruloid structures consisting of endothelial cells and pericytes $(H-E, x 200)$. B) A strong VEGF immunoreaction is noted in tumor cells and a focal-weak VEGF immunoreaction is noted in endothelial cells (BSA-DAB, $x 100)$. An immunoreaction is observed in endothelial cells with C) CD31 monoclonal antibody, and D) in pericytes with SMA monoclonal antibody (C-D; BSA-DAB, x200).

tumors $(1,4,10,12,15)$. GMP is less common in solid organ cancers other than glioblastoma. Some researchers have argued that, compared to MVD, GMP is a more reliable parameter in determining the tumors angiogenic phenotype. Studies on breast, lung, endometrium, and prostate cancers have shown that it is an unfavorable prognostic parameter (13).

A number of growth factors exhibit angiogenic activity in the adult central nervous system in both reactive and neoplastic states. These include basic fibroblast growth factor (bFGF), transforming growth factor-beta 1 (TGF-beta1), epidermal growth factor (EGF), and platelet- derived growth factor (PDGF) (5). However, a large amount of data indicates a major role for vascular endothelial growth factor (VEGF), also known as vascular permeability factor, in both cerebral vasculogenesis and angiogenesis $(5,11,16)$.

It has been suggested that GMP develops due to the effects of angiogenic growth factors synthesized by various cell types in response to hypoxic/ischemic injury. Various studies have shown that VEGF expressed by tumor cells, stroma, and proliferated endothelial cells plays an important role in GMP formation $(8,13,15)$. Some other studies, on the other hand, have reported that the deficiency of Caveolin-1 that is effective in differentiation, migration of endothelial cells and creation of capillary tubules may lead to GMP formation (7, 11). Studies on breast carcinomas have shown that hypoxiarelated genes are more intensely expressed in tumors exhibiting GMP pattern. It has been suggested that hypoxia developing in tumoral tissue induces VEGF release from various cells by leading to HIF1- a activation $(2,8,13)$.

Like many other tumor types, an increased angiogenic activity is an effective parameter in biological behavior of meningiomas (5). As far as we know, there are only a few studies showing the presence of GMP in intratumoral stroma of meningiomas. In a study of three cases, abnormal vascular structures containing prominent pericytic proliferation were located in the peritumoral stroma (1). In the case series of 7 patients reported by Robinson et al. the presence of pericytic proliferation was shown that formed glomeruloid structures 
in intratumoral stroma (12). Those 2 studies reported that GMP caused marked peritumoral edema and abnormal contrast uptake. Those researchers suggested that meningiomas containing GMP may be a different histological type $(1,12)$. In another report on a cystic meningioma GMP was observed on the gliotic cyst wall neighbouring the meningioma. In that study, an increased VEGF expression was demonstrated in tumoral cells and glial parenchyma neighboring the tumor (4). Similarly, in our case GMP was diffusely observed in intratumoral stroma and formed one of the main components of the tumor. Despite being more evident in tumor cells, VEGF expression was evident both in tumor tissue and areas of GMP. All of the cases reported in literature had cranial meningiomas. The mass in our case was located in the medulla spinalis. Absence of marked peritumoral edema in our patient may be related to both tumor location and absence of spinal cord invasion.

The histogenesis of GMP is a topic of debate. Ultrastructural examinations have shown that GMP is composed of proliferated endothelial cells and pericytes. The finding of a positive immunohistochemical reaction with both endothelial markers and smooth muscle markers in glomeruloid structures supports that opinion $(8,13)$. Wesseling et al. have suggested that GMP consists of in situ proliferation of microvascular cells that do not migrate to surrounding stroma (15). Some researchers have argued that GMPs are malformed vascular structures developing from tumor stroma $(1,5,12)$. Some other authors, on the other hand, have suggested that it represents an aggressive angiogenic phenotype affecting the biological behavior of the tumor $(2,8,13)$. In our patient, areas of GMP formed approximately $20 \%$ of tumor tissue. A proliferation was observed in areas of GMP, which caused an increase of layering in both endothelial and vascular smooth muscle cells. On the other hand, pericytic proliferation was more prominent in some GMP foci.

In conclusion, GMP is a rare pattern of angiogenesis in meningiomas. It is generally believed to be a reactive vascular proliferation secondary to ischemia in rapidly growing tumors although some researchers have classified meningomas exhibiting these features as a distinct histological subtype. Meningiomas cases containing GMP may be clinically and radiologically confused with malignant lesions because they cause a marked edema. In addition, this distinct histological form may prevent recognition of classical features of meningioma. Prospective studies with a larger sample size are needed to determine the biological importance of this pattern of angiogenesis.

\section{REFERENCES}

1. Akdemir $\mathrm{H}$, Kontaş $\mathrm{O}$, Oktem $\mathrm{IS}$, Tucer $\mathrm{B}$, Kafadar $\mathrm{H}$, Paşaoğlu A: A new subtype of meningioma. Neurosurg Rev 22:50-53, 1999

2. Akslen LA, Straume O, Geisler S, SørlieT, Chi JT, Aas T, BørresenDale AL, Lønning PE: Glomeruloid microvascular proliferation is associated with lack of response to chemotherapy in breast cancer. Br J Cancer 105(1):9-12, 2011
3. Alahmadi H, Croul SE: Pathology and genetics of meningiomas. Semin Diagn Pathol 28:314-324, 2011

4. Arai M, Kashihara K, Kaizaki Y: Enhancing gliotic cyst wall with microvascular proliferation adjacent to a meningioma. J Clin Neurosci 13:136-139, 2006

5. Barresi V: Angiogenesis in meningiomas. Brain Tumor Pathol 28:99-106, 2011

6. De Monte F: Current management of meningiomas. Oncology 9:83-91, 1995

7. Frank PG, Woodman SE, Park DS, Lisanti MP: Caveolin, caveolae and endothelial cell functions. Arterioscler Thromb Vasc Biol 23: 1161-1168, 2003

8. Goffin JR, Straume O, Chappuis PO, Brunet JS, Bégin LR, Hamel N, Wong N, Akslen LA, Foulkes WD: Glomeruloid microvascular proliferation is associated with p53 expression, germline BRCA1 mutations and an adverse outcome following breast cancer. Br J Cancer 89:1031-1034, 2003

9. Massimino ML, Griffoni G, Spisni E, Toni M, Tomasi V: Involvement of caveolae and caveolae-like domains in signalling, cell survival and angiogenesis. Cell Signal 14: 93-98, 2002

10. Matyja E, Grajkowska W, Nauman P, Ozieblo A, Bonicki W: Rosette-forming glioneuronal tumor of the fourth ventricle with advanced microvascular proliferation--a case report. Neuropathology 31:427-324, 2011

11. Park K, Kim JH, Nam DH, Lee Jl, Kim JS, Hong SC, Shin HJ, Eoh W, Park K: Vascular endothelial growth factor expression under ischemic stress in human meningiomas. Neurosci Lett 283: 45-48, 2000

12. Robinson JC, Challa VR, Jones DS, Kelly DL Jr: Pericytosis and edema generation: A unique clinicopathological variant of meningioma. Neurosurgery 39:700-706, 1996

13. Straume O, Chappuis PO, Salvesen HB, Halvorsen OJ, Haukaas SA, Goffin JR, Bégin LR, Foulkes WD, Akslen LA: Prognostic importance of glomeruloid microvascular proliferation indicates an aggressive angiogenic phenotype in human cancers. Cancer Res 62:6808-6811, 2002

14. Weidner N: Current pathologic methods for measuring intratumoral microvessel density within breast carcinoma and other solid tumors. Breast Cancer Res Treat 36:169-180, 1995

15. Wesseling P, Vandersteenhoven JJ, Downey BT, Ruiter DJ, Burger PC: Cellular components of microvascular proliferation in human glial and metastatic brain neoplasms. A light microscopic and immunohistochemical study of formalinfixed, routinely processed material. Acta Neuropathol (Berl) 85:508-514, 1993

16. Zhang ZG, Zhang L, Jiang Q, Zhang R, Davies K, Powers C, Bruggen NV, Chopp M: VEGF enhances angiogenesis and promotes blood-brain barrier leakage in the ischemic brain. J Clin Invest 106:829-838, 2000 